\title{
Taxonomic Study of Bacillus by Deoxyribonucleic Acid-Deoxyribonucleic Acid Hybridization and Interspecific Transformation
}

\author{
TATSUJI SEKI, TAKEHIRO OSHIMA, ${ }^{1}$ AND YASUJI OSHIMA \\ Department of Fermentation Technology, Osaka University, Yamadakami, Suita-shi, Osaka 565, Japan
}

\begin{abstract}
Taxonomic relationships between various species of Bacillus were studied, using 52 test strains of 8 species, by deoxyribonucleic acid (DNA)-DNA hybridization and by testing transformability of the auxotrophic and antibiotic resistance genetic markers. Results for species identification by the conventional taxonomic method described in Bergey's Manual (8th ed., 1974) showed good agreement with the DNA-DNA hybridization data for $B$. licheniformis (16 strains), $B$. pumilus (one strain), $B$. coagulans (three strains), B. megaterium (three strains), $B$. cereus (one strain), and $B$. brevis (one strain). However, data for 16 of 27 test strains of $B$. subtilis and related species indicated lower homology indexes (20 to $25 \%$ ) to the Marburg strain. Transformation of the auxotrophic markers to the wild type in the Marburg strain by DNA prepared from those strains showing lower homology to the Marburg strain was not detected, whereas the antibiotic resistance markers were transformed with the same DNA preparation. Transformation of the antibiotic resistance markers to the Marburg strain by DNA prepared from some strains of species other than B. subtilis, e.g., B. licheniformis and $B$. pumilus, was also detected, whereas transformation of the auxotrophic markers was not. These results strongly suggest that these two groups of $B$. subtilis should be divided into two different species. However, evidence suggesting the existence of a core region of DNA among a wide variety of species of Bacillus was presented.
\end{abstract}

The genetic backgrounds and methods of genetic exchange of a wide variety of Bacillus species, important microorganisms in the fermentation industry, are not fully understood, except for the Marburg strains, a restricted group of strains belonging to $B$. subtilis, in which genetic recombination by transformation is possible. However, it has been claimed by Welker and Campbell $(27,28)$ that several strains of $B$. subtilis used in the commercial production of $\alpha$-amylase belong to a group distinctly different from the Marburg strain. Among species of Bacillus, including these two types of $B$. subtilis, no close homogeneity was detected in the base sequence of deoxyribonucleic acid (DNA) by DNA-DNA hybridization $(19,26)$. On the other hand, there is some evidence suggesting the existence of a core region(s) of DNA coding for $4 S, 16 S$, and $23 S$ ribonucleic acid (RNA) molecules and ribosomal proteins based on DNA-RNA hybridization $(8,9)$ and the transformability of resistance markers for some antibiotics $(9,10,13)$.

In this communication, taxonomic relationships between various species of Bacillus are

'Present address: Central Research Institute, Suntory Ltd., Hirose, Shimamoto-cho, Osaka 618 Japan. discussed with respect to the close parallelism between homology indexes from DNA-DNA hybridization studies and patterns of transformability of the auxotrophic and antibiotic resistance characteristics. Evidence is also presented for the existence of a core region of DNA among a wide variety of Bacillus species.

\section{MATERIALS AND METHODS}

Strains. The strains used are listed in Table 1. All of them belong to a group of the genus Bacillus that is characterized by formation of indefinitely swollen sporangia, except for one strain of B. brevis. Thirtysix strains were obtained from authentic sources, and 20 strains of three Bacillus species were newly isolated from soil. Escherichia coli $\mathrm{K}-12$ was also used as a test strain. The taxonomic significance of all strains was critically examined according to Bergey's Manual (7th [22] and 8th [11] editions) by the method of Smith et al. (23). All strains were stored at room temperature on Difco nutrient agar slants, supplemented with $200 \mu \mathrm{g}$ of thymine per $\mathrm{ml}$ if necessary. Spontaneously occurring streptomycin- and/or erythromycinresistant mutants were isolated. These resistant mutants could grow on medium containing $1 \mathrm{mg}$ of streptomycin and/or $1 \mu \mathrm{g}$ of erythromycin per $\mathrm{ml}$. Four thymine auxotrophic mutants were isolated from $B$. subtilis strain KA-63, B. lichenformis strains IFO 12107 and S207, and B. megaterium strain IAM 1030 
TABLE 1. List of strains used

\begin{tabular}{|c|c|}
\hline Strain & Remarks \\
\hline \multicolumn{2}{|l|}{ B. subtilis } \\
\hline 168 trp & $\Leftarrow \mathrm{S}$. Yuki $\Leftarrow$ J. L. Farmer and F. Rothman \\
\hline 168 trp thy & $\Leftarrow \mathrm{S}$. Yuki $\Leftarrow$ J. L. Farmer and F. Rothman \\
\hline W23 & $\Leftarrow \mathrm{S}$. Yuki $\Leftarrow$ J. L. Farmer and F. Rothman \\
\hline W23 his thy & $\Leftarrow \mathrm{S}$. Yuki $\Leftarrow \mathrm{J} . \mathrm{L}$. Farmer and F. Rothman \\
\hline OUT $^{a} 8235$ & $\Leftarrow \mathrm{IFO}^{b} 3009$ (B. natto Sawamura) $\Leftarrow$ FAT $^{c} 09$ \\
\hline IFO 3134 & $\begin{array}{l}\Leftarrow \text { lowa State College 1A29 } \Leftarrow \text { ATCC }^{d} 6633 \\
\Leftarrow \text { N. R. Smith, } 231\end{array}$ \\
\hline IFO 12210 & $\Leftarrow \mathrm{IAM}^{e} \Leftarrow$ H. J. Cohn, a Marburg strain \\
\hline IFO 13169 & $\leftarrow \mathrm{S}$. Yamauchi from natto (B. natto Sawamura) \\
\hline IFO 3026 & $\mathrm{RTCI}^{\prime}$ \\
\hline KA-63 & OUT stock culture $\Leftarrow$ G. Terui (15) \\
\hline IAM $1523(\mathrm{~K})$ & $(14)$ \\
\hline OUT 8108 & $\Leftarrow$ IFO $3034 \Leftarrow$ RTCI \\
\hline OUT 8109 & $\Leftarrow$ IFO 3035 \\
\hline OUT 8110 & $\Leftarrow$ IFO $3037 \Leftarrow$ RTCI \\
\hline IFO 3022 & $\Leftarrow \mathrm{RTCI}$ \\
\hline $1-18^{g}$ & $\Leftarrow \mathrm{S}$. Yuki; marked with his B2 \\
\hline LMAH $^{g}$ & $\Leftarrow \mathrm{H}$. Yoshikawa; marked with leuA8 met B5 purA 16 his $A$ \\
\hline B. subtilis subsp. niger OUT 8111 & $\Leftarrow$ IFO $3108 \Leftarrow$ RTCI \\
\hline B. subtilis subsp. attrimus IFO 3214 & $\Leftarrow$ Miyazaki University (Y. Ishimaru, Y15) \\
\hline B. subtilis subsp. amyloliquefaciens $\mathrm{F}$ & $\Leftarrow \mathrm{T}$. Yamamoto (J. Fukumoto) \\
\hline \multicolumn{2}{|c|}{ B. amylosolvens OUT 8341} \\
\hline \multicolumn{2}{|l|}{ B. licheniformis } \\
\hline IFO 12107 & $\Leftarrow$ ATCC $9945 \mathrm{a} \Leftarrow \mathrm{C}$. B. Thorne \\
\hline IFO 12195 & $\Leftarrow \mathrm{NCIB}^{h} 6346 \Leftarrow \mathrm{NCTC}^{i} 6346$ (N. R. Smith, 243; ATCC 9800) \\
\hline IFO 12196 & $\Leftarrow$ NCIB $8061 \Leftarrow$ ATCC $9789 \Leftarrow$ N. R. Smith, 978 \\
\hline IFO 12197 & $\Leftarrow$ NCIB $8062 \Leftarrow$ ATCC $9945 \Leftarrow$ N. R. Smith, 712 \\
\hline IFO 12199 & $\Leftarrow$ NCIB $8874 \Leftarrow$ ATCC $10716 \Leftarrow$ N. R. Smith, 1330 \\
\hline IFO 12200 & $\Leftarrow$ NCIB $9375 \Leftarrow$ R. E. Gordon (N. R. Smith, 1264; ATCC 14580) \\
\hline IFO 12201 & $\begin{array}{l}\Leftarrow \text { NCIB } 8537 \Leftarrow \text { Technische Hogeschool, Delft (W. Verhoeven, strain } \\
\text { HO) }\end{array}$ \\
\hline B. pumilus IFO 12110 & $\Leftarrow$ NRRL $^{j}$ B- $1489 \Leftarrow$ N. R. Smith, 236 \\
\hline \multicolumn{2}{|l|}{ B. coagulans } \\
\hline IFO 3557 & $=\mathrm{T}$. Harada (Institute of Scientific and Industrial Research, Osaka Ur \\
\hline IFO 3886 & $\Leftarrow \operatorname{RIFY}^{k}(\mathrm{O}$. Nakayama, P22) \\
\hline IFO 3887 & $\Leftarrow$ RIFY (O. Nakayama, A22) \\
\hline \multicolumn{2}{|l|}{ B. megaterium } \\
\hline IFO 3970 & $\begin{array}{l}\Leftarrow \text { Tottori Univ. } \Leftarrow \text { RIMD }^{l} \Leftarrow \text { University of California (J. H. Northrop, } \\
\text { KM) }\end{array}$ \\
\hline \multicolumn{2}{|r|}{ - } \\
\hline \multicolumn{2}{|l|}{ B. cereus IAM 1229} \\
\hline B. brevis IFO 12334 & $\Leftarrow$ ATCC $10027 \Leftarrow$ N. R. Smith, 605 \\
\hline Escherichia coli $\mathrm{K}-12$ & Our stock culture \\
\hline \multicolumn{2}{|l|}{ B. subtilis } \\
\hline $\mathrm{S} 202$ & Isolated from soil \\
\hline S204 & Isolated from soil \\
\hline S219 & Isolated from soil \\
\hline $\mathrm{S} 229$ & Isolated from soil \\
\hline $\mathrm{S} 234$ & Isolated from soil \\
\hline $\mathrm{S} 236$ & Isolated from soil \\
\hline S237 & Isolated from soil \\
\hline $\mathrm{S} 239$ & Isolated from soil \\
\hline $\mathrm{S} 242$ & Isolated from soil \\
\hline $\mathrm{S} 294$ & Isolated from soil \\
\hline
\end{tabular}

by cultivating cells in Spizizen minimum medium (24) containing $50 \mu \mathrm{g}$ of 2,4-diamino-5-( $3^{\prime} 4^{\prime} 4^{\prime}$-trimethoxy)benzyl pyrimidine (trimethoprim; Sigma) per $\mathrm{ml}$ and $200 \mu \mathrm{g}$ of thymine per $\mathrm{ml}$ according to Stacey and Simson (25). Since almost all clones isolated as thymine auxotrophs required more than $25 \mu \mathrm{g}$ of thymine per $\mathrm{ml}$ for growth, cell suspensions at appropriate dilutions were spread on plates of Spizizen minimum medium containing a reduced amount of thymine $(2 \mu \mathrm{g} /$ $\mathrm{ml})$. The rare $\left(10^{-3}\right)$ colonies that appeared spontane- 
TABLE $1-$ Continued

\begin{tabular}{ll}
\hline \multicolumn{1}{c}{ Strain } & Remarks \\
\hline B. licheniformis & Isolated from soil \\
S84 & Isolated from soil \\
S207 & Isolated from soil \\
S208 & Isolated from soil \\
S212 & Isolated from soil \\
S227 & Isolated from soil \\
S240 & Isolated from soil \\
S256 & Isolated from soil \\
S333 & Isolated from soil \\
B. megaterium S211 & Isolated from soil \\
\hline
\end{tabular}

${ }^{a}$ Department of Fermentation Technology, Osaka University, Suita, Japan.

${ }^{o}$ Institute for Fermentation, Osaka, Japan.

${ }^{c}$ Faculty of Agriculture, University of Tokyo, Tokyo, Japan.

${ }^{d}$ American Type Culture Collection, Rockville, Md.

${ }^{e}$ Institute of Applied Microbiology, University of Tokyo, Tokyo, Japan.

${ }^{t}$ Research Laboratories, Takeda Chemical Industries Ltd., Osaka, Japan.

These two Marburg strains were used as the recipients for the transformation experiments.

${ }^{h}$ National Collection of Industrial Bacteria, Torry Research Station, Aberdeen, Scotland.

${ }^{i}$ National Collection of Type Cultures, London, England.

'Northern Utilization Research and Development Division, U.S. Department of Agriculture, Peoria, Ill.

${ }^{k}$ Research Institute of Fermentation, Yamanashi University, Kofu, Japan.

' Research Institute for Microbial Diseases, Osaka University, Suita, Japan.

ously on this plate were picked up, and it was confirmed that they were able to grow on Spizizen minimum medium provided it contained $2 \mu \mathrm{g}$ of thymine per $\mathrm{ml}$.

Media and growth conditions for cells in the preparation of DNA. Cells were grown at $37 \mathrm{C}$ in nutrient broth (Difco) or Penassay broth (Difco), except for those of $B$. coagulans. For cultivation of $B$. coagulans, nutrient medium composed of polypeptone (Digo Eiyo; 1\%), yeast extract (Oriental Yeast; 1\%), and glucose $(1 \%), \mathrm{pH} 7.0$, was used for cultivation at $48 \mathrm{C}$. Cells were harvested by centrifugation from culture in the early stationary phase $(5$ to $10 \mathrm{~h}$ of cultivation, depending on the strain, medium, and inoculum size), and were washed twice with $1 \times$ SSC $(0.15 \mathrm{M} \mathrm{NaCl}$ and $0.015 \mathrm{M}$ trisodium citrate, $\mathrm{pH}$ 7.0) and once with saline-EDTA $(0.15 \mathrm{M} \mathrm{NaCl}$ and $0.1 \mathrm{M}$ ethylenediamine tetraacetic acid, $\mathrm{pH}$ 8.4). Cells were resuspended in a small amount of salineEDTA, and DNA was extracted.

Tritium-labeled DNA was prepared from the thymine-requiring mutant cultivated in Spizizen minimum medium containing $1 \%$ Casamino Acids (Difco), $2 \mu \mathrm{g}$ of $\left[{ }^{3} \mathrm{H}\right]$ thy mine or -thymidine per $\mathrm{ml}(1.25 \mu \mathrm{Ci}$ of [methyl ${ }^{3} \mathrm{H}$ ] thymine or -thymidine per $\mu \mathrm{g}$; The Radiochemical Centre Ltd., Amersham, England), and $200 \mu \mathrm{g}$ of L-tryptophan per $\mathrm{ml}$, if required. Since cells of $B$. subtilis strain KA-63 agglutinated in the above medium, $1 \%$ of the polypeptone was replaced with Casamino Acids. It was confirmed that virtually no radioactivity was incorporated into RNA by this labeling method.

Preparation of DNA. DNA was prepared by the method of Marmur (18). RNA in the crude DNA solution was digested at $37 \mathrm{C}$ for $30 \mathrm{~min}$ by the addition of $50 \mu \mathrm{g}$ of crystalline pancreatic ribonuclease per ml (Sigma), of which the deoxyribonuclease had been inactivated by heating at $80 \mathrm{C}$ for $10 \mathrm{~min}$. For further purification, DNA was precipitated with isopropyl alcohol in the presence of $0.3 \mathrm{M}$ sodium acetate. The specific radioactivity of purified ${ }^{3} \mathrm{H}$ labeled DNA thus obtained was about 40,000 counts/ min per $\mu \mathrm{g}$ of DNA. The purified DNA preparation was still contaminated with about $10 \%$ RNA determined by the orcinol reaction $(21)$, but protein was not detected by the method of Lowry et al. (17). The amount of DNA was determined by the method of Burton (4), using 2-deoxyadenosine monophosphate as standard. For determination of the DNA radioactivity in solution, DNA (less than $25 \mu \mathrm{g}$ ) in an appropriate amount of sample was precipitated by the addition of cold trichloroacetic acid in a final concentration of $5 \%$. The precipitated DNA was collected on a membrane filter ( $25 \mathrm{~mm}$ in diameter) and washed with $10 \mathrm{ml}$ of cold acid (5\%); the filter was dried in a vacuum ( $<20$ torr) oven at $80 \mathrm{C}$ for $30 \mathrm{~min}$, and its radioactivity was measured. Transformation was performed by using the DNA preparation without the ribonuclease treatment.

Preparation of DNA filter. The DNA filter was prepared according to the method of Gillespie and Spiegelman (12) with partial modification. One milliliter of DNA solution containing $25 \mu \mathrm{g}$ of DNA in $1 \times$ SSC was denatured by adding $1 \mathrm{ml}$ of $0.3 \mathrm{M} \mathrm{NaOH}$ solution and allowing it to stand for $10 \mathrm{~min}$ at room temperature; $\mathrm{pH}$ was neutralized with $1 \mathrm{M} \mathrm{HCl}$. Denatured DNA solution was adjusted to $6 \times$ SSC by the addition of an appropriate amount of $10 \times \mathrm{SSC}$ and passed at moderate speed (about $3 \mathrm{ml} / \mathrm{min}$ ) through a nitrocellulose membrane filter $(25 \mathrm{~mm}$ in diameter, $0.45-\mu \mathrm{m}$ pore size; Sartorius Membranfilter GMBH, West Germany) that had been presoaked in $6 \times$ SSC. The DNA filter was subsequently dried for $2 \mathrm{~h}$ at room temperature and for $2 \mathrm{~h}$ in a 
vacuum ( $<20$ torr) oven at $80 \mathrm{C}$. The amount of DNA immobilized on a membrane filter (disk DNA) was usually $25 \mu \mathrm{g}$ for the reason described in Results. Fixation of DNA on a membrane filter was almost complete by this procedure, and more than $97 \%$ of the DNA was retained by the filter during incubation of the DNA filter under standard annealing conditions.

DNA-DNA hybridization. The procedure for DNA-DNA hybridization followed that described by McConaughy et al. (20) with partiaj modification. Tritium-labeled DNA was diluted to a sout $20 \mu \mathrm{g} / \mathrm{ml}$ in $1 \times \mathrm{SSC}$ and denatured by the addition of 0.5 volume of $0.3 \mathrm{M} \mathrm{NaOH}$ solution. The solution was sonicated by an ultrasonic apparatus (model 4280 , Kaijo Denki Co. Ltd., Tokyo) at $200 \mathrm{~W}, 19.5 \mathrm{kHz}$ for 3 min at $4 \mathrm{C}$. Appropriate amounts of formamide, salt, and $\mathrm{HCl}$ for neutralization of $\mathrm{pH}$ were then added to make the reaction mixture up to $6 \times \mathrm{SSC}$-formamide (50\%; mixture of $12 \times \mathrm{SSC}$ with the same volume of guaranteed reagent grade of formamide) and to an appropriate concentration of DNA (usually $0.5 \mu \mathrm{g}$ / $\mathrm{ml}$ ). One milliliter of this DNA solution (input DNA) was incubated with the disk DNA in a capped, small glass vial. These vials were shaken gently at 55 strokes (5 $\mathrm{cm}$ in amplitude) per $\mathrm{min}$ at $37 \mathrm{C}$ for $22.5 \mathrm{~h}$ unless otherwise stated. At the end of the incubation period, $5 \mathrm{ml}$ of $6 \times$ SSC-formamide $(50 \%)$ was poured into a vial and fluid was discarded by suction. A filter was washed in $5 \mathrm{ml}$ of $3 \mathrm{mM}$ tris(hydroxymethyl)aminomethane-hydrochloride buffer ( $\mathrm{pH} \mathrm{9.0)}$. Each side of the filter was subsequently rinsed with this buffer and was washed again with $10 \mathrm{ml}$ of the same buffer by filtration. The washed filter was dried in a vacuum oven at $80 \mathrm{C}$ and placed in $10 \mathrm{ml}$ of scintillation fluid containing $5 \mathrm{~g}$ of 2,5-diphenyloxazole per liter of toluene. The amount of input DNA bound to the disk DNA was estimated by counting the radioactivity of the membrane filter, using a liquid scintillation counter (Beckman model LS-250). The DNA homology was represented as the homology index, i.e., the percentage of input DNA bound to a certain disk DNA relative to the homologous reaction. Since nonspecific binding of input DNA onto a filter was less than $0.5 \%$ of the total input DNA, it was not necessary to preincubate the DNA filter in Denhardt medium (7).

Dissociation of hybrid DNA. To obtain the thermal dissociation profile, a DNA-DNA hybrid was formed on a membrane filter as described above except that 2.5 instead of $0.5 \mu \mathrm{g}$ of ${ }^{3} \mathrm{H}$-labeled input DNA per $\mathrm{ml}$ of annealing mixture was used. The filter on which the hybrid duplex was formed was incubated with $1.5 \mathrm{ml}$ of $6 \times$ SSC-formamide $(50 \%)$ at a particular temperature for $10 \mathrm{~min}$. DNA eluted from the filter was collected on a filter after precipitation with trichloroacetic acid, and the radioactivity was counted by the same method used for determining the radioactivity of DNA in a solution. The DNA filter was further incubated in the same way with a new batch of $6 \times$ SSC-formamide $(50 \%)$ at higher temperature.

For the secondary hybridization experiment, the DNA sample was prepared by dissociation of the DNA hybrid duplex on disk DNA by incubating in $1.5 \mathrm{ml}$ of $6 \times$ SSC-formamide $(50 \%)$ at $70 \mathrm{C}$ for $10 \mathrm{~min}$ and rapidly cooling in an ice bath. The secondary hybridi- zation was performed by adding a portion $(1.0 \mathrm{ml})$ of this DNA solution as input DNA in a subsequent filter hybridization.

Transformation. Competent cells were obtained by the method of Anagnostopoulos and Spizizen (1). Transformation was performed by incubating $0.5 \mathrm{ml}$ of donor DNA solution containing $5 \mu \mathrm{g}$ of DNA per $\mathrm{ml}$ in $1 \times$ SSC with $4 \mathrm{ml}$ of a culture of competent cells (containing $0.5 \times 10^{8}$ to $1.0 \times 10^{8}$ cells per $\mathrm{ml}$ ) for 15 min at $37 \mathrm{C}$ and then adding $0.5 \mathrm{ml}$ of deoxyribonuclease (250 $\mu \mathrm{g} / \mathrm{ml}$; Sigma) and incubating for $30 \mathrm{~min}$ at 37 C. In the case of transformation for resistant traits against streptomycin and erythromycin, recipient cells incubated with DNA were incubated at $37 \mathrm{C}$ for an additional $2 \mathrm{~h}$ after deoxyribonuclease treatment to allow phenotypic expression of the transformants. Transformants were detected by spreading the reaction mixture, appropriately diluted or condensed, on test media composed of Spizizen minimum medium supplemented with nutrients $(20 \mu \mathrm{g}$ each of amino acids and $10 \mu \mathrm{g}$ of adenine per $\mathrm{ml}$. if required) for the auxotrophic markers and on meat extract-peptone medium (meat extract [Waco Pure Chemical Co. Ltd.], $1 \%$; polypeptone, $1 \%$; $\mathrm{NaCl}, 0.2 \%$; $\mathrm{pH} 7.0$ ) supplemented with $1 \mathrm{mg}$ of streptomycin per $\mathrm{ml}$ or 1.0 or $0.2 \mu \mathrm{g}$ of erythromycin per $\mathrm{ml}$ for testing resistance to these antibiotics.

\section{RESULTS}

Establishment of hybridization procedure. The effect of input DNA concentration on the formation of the hybrid DNA duplex with a constant amount $(25 \mu \mathrm{g})$ of disk DNA was tested in $1 \mathrm{ml}$ of $6 \times \mathrm{SSC}$-formamide $(50 \%)$ by annealing at $37 \mathrm{C}$ for $23 \mathrm{~h}$ with the homologous combination of DNA extracted from $B$. subtilis strain 168 for both disk and ${ }^{3} \mathrm{H}$-labeled input DNAs. The results clearly indicated that the amount of input DNA hybridized with the disk DNA was directly proportional to the amount of input DNA in the concentration range of 0.025 to $5 \mu \mathrm{g}$ per $\mathrm{ml}$ (Fig. 1). It was observed, however, that the percentage of input DNA hybridized with the disk DNA was strictly constant (approximately $48 \%$ in the case of homologous combination with DNA of strain 168).

The homology indexes of DNA were also determined by using a constant amount $(0.5 \mu \mathrm{g})$ of input DNA prepared from $B$. subtilis strain 168 and various amounts of disk DNA from three strains of $B$. subtilis (168, OUT 8111, and KA-63) and strain IFO 3886 of $B$. coagulans. The amount of input DNA bound to disk DNA was significantly increased by increasing the amount of disk DNA (Fig. 2A). However, the homology index between certain combinations of DNAs was unrelated to the amount of disk DNA and showed a strictly constant value from 10 to $100 \mu \mathrm{g}$ of DNA per filter, taking the amount of input DNA hybridized with the disk DNA in homologous combination of DNA of strain 168 as $100 \%$ (Fig. 2B). 
The effect of incubation period on the amount of binding of input DNA was studied by incubating $25 \mu \mathrm{g}$ of disk DNA and $0.5 \mu \mathrm{g}$ of input DNA at $37 \mathrm{C}$ in $1 \mathrm{ml}$ of $6 \times$ SSC-formamide $(50 \%)$ medium. Results showed only a slight increase in the homology indexes due to prolonged incubation in the heterologous combination of DNAs, whereas the amounts of duplex formation were significantly affected (Fig. 3). Based on the above observations, annealing

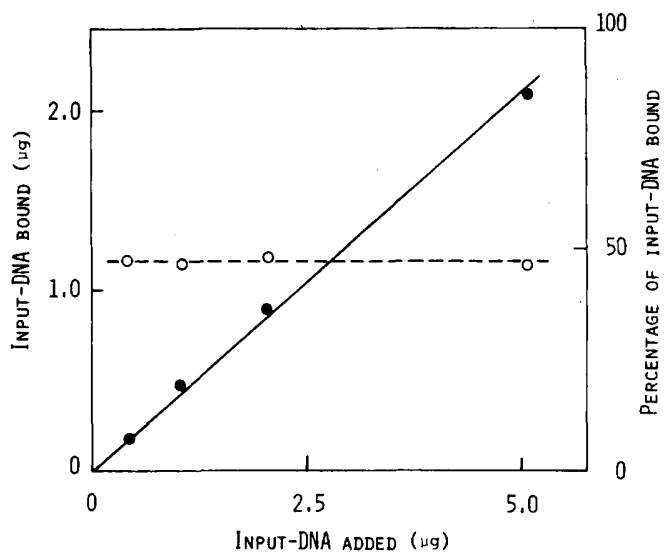

FIG. 1. Effect of the amount of input DNA on the formation of DNA hybrid duplex. A DNA filter carrying $25 \mu \mathrm{g}$ of unlabeled DNA extracted from $B$. subtilis 168 was incubated at $37 \mathrm{C}$ for $23 \mathrm{~h}$ in $1 \mathrm{ml}$ of $6 \times$ SSC-formamide $(50 \%)$ containing various amounts of ${ }^{3} \mathrm{H}$-labeled DNA prepared from the same strain. The amount of bound DNA was determined by counting the radioactivity of the filter. Symbols: Amount of bound input DNA; O, percentage of bound input DNA. conditions consisting of the DNA filter prefixed with $25 \mu \mathrm{g}$ of nonlabeled DNA (disk DNA), 0.5 $\mu \mathrm{g}$ of ${ }^{3} \mathrm{H}$-labeled DNA (input DNA) in $1 \mathrm{ml}$ of $6 \times$ SSC-formamide (50\%), and incubation at $37 \mathrm{C}$ for $22.5 \mathrm{~h}$ with gentle shaking were selected as the standard procedure in determining the homology index.

DNA homologies. The DNA homology data obtained from hybridization of the ${ }^{3} \mathrm{H}$-labeled input DNAs prepared from three strains of $B$. subtilis (168, W23, and KA-63), one strain of $B$. megaterium (IAM 1030), and two strains of $B$. licheniformis (IFO 12107 and S207) with disk DNA extracted from various strains are shown in Table 2. The homology indexes had essentially the same values by reciprocal determinations in all the possible combinations of strains. The amount of input DNA hybridized with disk DNA in homologous combination showed virtually the same value in independent experiments and ranged between 45 and $60 \%$ of the total input DNA, depending on the strain.

Among the different strains of $B$. subtilis, the DNA homology indexes fell roughly into two groups, one which showed higher (60 to $100 \%$ ), and the other lower (about 20\%) homology to the DNA prepared from strain 168 . This classification gave good agreement with data obtained from the other reference strains of $B$. subtilis, W23 and KA-63.

Strains B. subtilis subsp. amyloliquefaciens F, B. amylosolvens OUT 8341, and B. subtilis IAM 1523, well known for their potent productivity of $\alpha$-amylase, were found to be closely related to $B$. subtilis strain KA-63 since they showed 89 to $94 \%$ homology indexes to the DNA

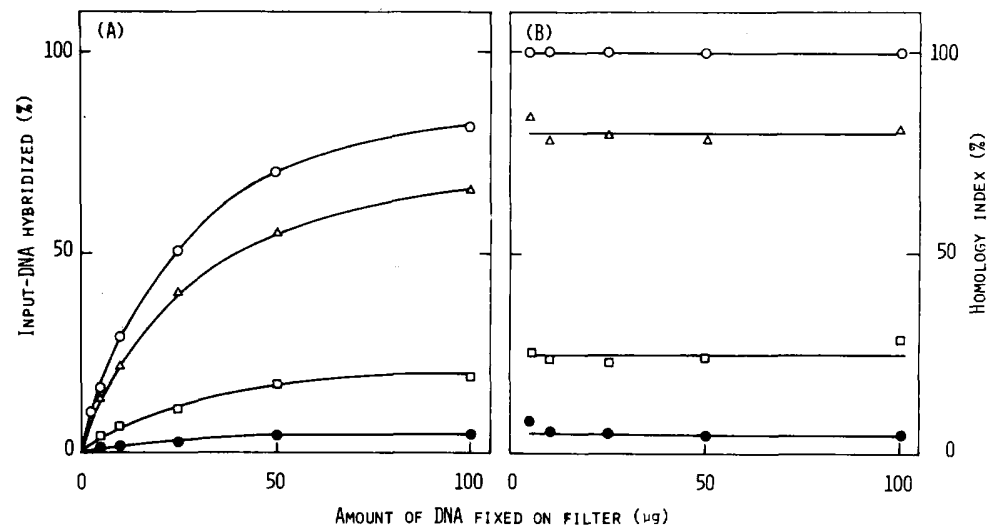

FIG. 2. Effect of the amount of disk DNA on the hybridization of DNA. The hybridization was performed at $37 \mathrm{C}$ for $22.5 \mathrm{~h}$ by using a constant amount $(0.5 \mu \mathrm{g})$ of ${ }^{3} \mathrm{H}$-labeled input DNA prepared from B. subtilis 168 with

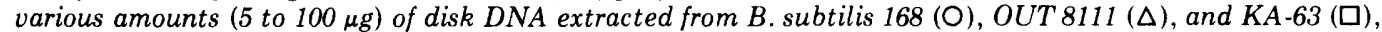
and $B$. coagulans IFO $3886(\mathbf{O})$, in $1 \mathrm{ml}$ of $6 \times S S C$-formamide $(50 \%)$ reaction mixture. Percentage hybridization of input DNA $(A)$ and homology indexes taking $B$. subtilis 168 as the standard $(B)$ were calculated from the same data. 


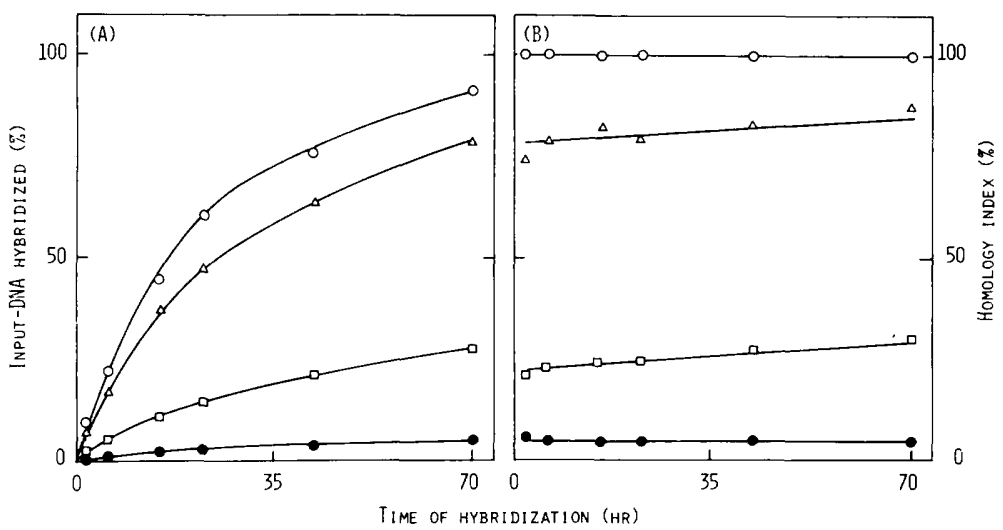

FIG. 3. Time course of the formation of DNA hybrid duplex. The DNA hybrid duplex was formed on the disk $D N A$ prefixed with $25 \mu \mathrm{g}$ of DNA prepared from B. subtilis $168(\mathrm{O})$, OUT $8111(\triangle)$, and KA-63 (口), and B. coagulans IFO $3886(\mathbf{O})$, with $0.5 \mu \mathrm{g}$ of ${ }^{3} \mathrm{H}$-labeled input DNA extracted from B. subtilis 168 in $1 \mathrm{ml}$ of $6 \times$ $S S C$-formamide $(50 \%)$ reaction mixture. Percentage hybridization of input DNA $(A)$ and homology indexes taking $B$. subtilis 168 as the standard $(B)$ were calculated from the same data.

of strain KA-63. It is evident that all of them fell into a group of strains of $B$. subtilis distinct from strain 168, the Marburg strain. It has been suggested by Welker and Campbell that $B$. subtilis subsp. amyloliquefaciens should be placed in a group taxonomically different from the Marburg strain of $B$. subtilis because of its different guanine plus cytosine content, lower homogeneity (14.7 to $18.4 \%)$ of DNA, failure to give cross-transduction of auxotrophic markers by phage SP-10 (27), and the characteristic difference in its $\alpha$-amylase (28), in addition to some physiological and biochemical differences in cultures of these strains (27). The data on the DNA homology among these strains (Table 2) clearly support the same conclusion. However, it was inferred that the group of strains of $B$. subtilis, including $B$. subtilis subsp. amyloliquefaciens and the others that are distinct from the Marburg strain, might have a closer homogeneity to the Marburg strain than to the other species of Bacillus so far examined.

Two strains of $B$. subtilis, B. subtilis subsp. niger strain OUT 8111 and $B$. subtilis subsp. attrimus strain IFO 3214 , were found to be of the same group as the Marburg strain since they showed 78 and $96 \%$ homology to strain 168, respectively. Close homogeneity was inferred between $B$. subtilis strains IFO 12210 and 168 since they showed $100 \%$ homology; this result was expected since both of them are Marburg strains. It is noteworthy that the homology index of B. subtilis strain IFO 3134 (ATCC 6633 ) to strain 168 was $70 \%$. This observation was in accord with the data of Lovett and Young (16) but not consistent with those of Dubnau et al. (9), since they observed lower homology between the strains $(15 \%)$.
Among ten strains of $B$. subtilis newly isolated from soil, two strains, S237 and S239, were closely related to strain 168 (94 and 96\% DNA homology, respectively), whereas the other eight strains were related to strain KA-63 (65 to $88 \%)$. However, strain S239 was found to differ from the standard description of $B$. subtilis in Bergey's Manual (22) in that it did not produce acid from mannitol or xylose. Among the strains showing close similarity to strain KA-63 in their DNA homology, strains S234 and S242 did not produce acid from xylose or arabinose. These two strains were different in that strain S242 produced acid from lactose without gas production whereas strain S234 did not.

Two strains of $B$. licheniformis, IFO 12107 and S207, were used as reference strains for preparation of ${ }^{3} \mathrm{H}$-labeled input DNA. These two strains should be the same species according to the close similarity in their DNA homology and the standard description of the species $(11,22)$ by conventional taxonomic studies. It was found that the DNA homology between them was approximately $80 \%$ (76 and $83 \%$ in reciprocated combination).The homology indexes of DNA among 16 strains of $B$. lichenifor$m i s, 7$ strains from the authentic culture collections (IFO) and 9 strains from soil, ranged from 61 to $100 \%$, and no significant differences were found by using two input DNAs from the above-mentioned reference strains. Thus, the DNA hybridization data also indicated that all of them should be placed in the same species, i.e., B. licheniformis. Among them, strains S212, S240, and S244 showed essentially $100 \%$ of DNA homology with strain S207. These four strains showed the same morphological and physiological characteristics and corresponded 
TABLE 2. DNA homologies among various strains of Bacillus ${ }^{a}$

\begin{tabular}{|c|c|c|c|c|c|c|}
\hline \multirow[b]{2}{*}{ Disk DNA } & \multicolumn{6}{|c|}{ Input DNA } \\
\hline & $\begin{array}{c}\text { B. subtilis } \\
168\end{array}$ & $\begin{array}{l}\text { B. subtilis } \\
\text { W23 }\end{array}$ & $\begin{array}{l}\text { B. subtilis } \\
\text { KA-63 }\end{array}$ & $\begin{array}{c}B . \\
\text { licheniformis } \\
\text { IFO } 12107\end{array}$ & $\begin{array}{c}B . \\
\text { licheniformis } \\
\text { S207 }\end{array}$ & $\begin{array}{l}\text { B. megaterium } \\
\text { IAM } 1030\end{array}$ \\
\hline \multicolumn{7}{|l|}{ B. subtilis } \\
\hline 168 & $100 \%$ & $67 \%$ & $21 \%$ & $11 \%$ & $15 \%$ & $6 \%$ \\
\hline W23 & 70 & 100 & 22 & 12 & $-^{b}$ & - \\
\hline OUT 8235 & 67 & 59 & 18 & 12 & - & - \\
\hline IFO 3134 & 70 & 64 & 21 & 10 & - & - \\
\hline IFO 12210 & 100 & - & 22 & 9 & - & - \\
\hline IFO 13169 & 70 & 51 & 15 & 10 & - & - \\
\hline var. niger OUT 8111 & 78 & 72 & 24 & 13 & - & - \\
\hline var. attrimus IFO 3214 & 96 & 68 & 21 & 12 & - & - \\
\hline IFO 3026 & 98 & - & 23 & 10 & - & - \\
\hline $\mathbf{S} 237$ & 94 & - & 28 & 13 & 18 & 5 \\
\hline S239 & 96 & - & 30 & 13 & 16 & 5 \\
\hline KA-63 & 23 & 21 & 100 & 13 & 15 & 5 \\
\hline IAM 1523 & 20 & 20 & 89 & 12 & - & - \\
\hline OUT 8108 & 20 & 19 & 71 & 11 & - & - \\
\hline OUT 8109 & 17 & 17 & 70 & 12 & - & - \\
\hline OUT 8110 & 17 & 17 & 66 & 11 & - & - \\
\hline IFO 3022 & 17 & 17 & 67 & 12 & 一 & - \\
\hline $\mathrm{S} 202$ & 32 & - & 88 & 15 & - & - \\
\hline S204 & 25 & - & 79 & 9 & - & - \\
\hline S219 & 33 & - & 90 & 15 & - & - \\
\hline $\mathrm{S} 229$ & 36 & - & 89 & 17 & - & - \\
\hline $\mathrm{S} 234$ & 24 & - & 66 & - & - & - \\
\hline $\mathrm{S} 236$ & 21 & - & 74 & 13 & 18 & 5 \\
\hline S242 & 26 & - & 65 & 10 & 14 & 2 \\
\hline $\mathrm{S} 294$ & 19 & - & 77 & 12 & 15 & 4 \\
\hline $\begin{array}{l}\text { B. subtilis subsp. amylo- } \\
\text { liquefaciens } \mathrm{F}\end{array}$ & 25 & - & 92 & 13 & 15 & 5 \\
\hline \multicolumn{7}{|l|}{ B. licheniformis } \\
\hline IFO 12107 & 8 & 9 & 10 & 100 & 83 & 6 \\
\hline IFO 12195 & 9 & 9 & 9 & 61 & 75 & 2 \\
\hline IFO 12196 & 12 & - & 13 & 75 & 105 & 5 \\
\hline IFO 12197 & 11 & 11 & 13 & 100 & - & - \\
\hline IFO 12199 & 13 & - & 15 & 68 & 70 & 5 \\
\hline IFO 12200 & 12 & - & 15 & 64 & 86 & 5 \\
\hline IFO 12201 & 14 & - & 14 & 64 & 94 & 5 \\
\hline S84 & 12 & - & 12 & 84 & 94 & 5 \\
\hline S207 & 11 & - & 12 & 76 & 100 & 5 \\
\hline $\mathrm{S} 208$ & 13 & - & 12 & 80 & 82 & 5 \\
\hline $\mathrm{S} 212$ & 15 & - & 13 & 71 & 103 & 5 \\
\hline S227 & 11 & - & 14 & 81 & 89 & 5 \\
\hline $\mathrm{S} 240$ & 9 & - & 9 & 76 & 116 & 4 \\
\hline S244 & 14 & - & 14 & 72 & 108 & 6 \\
\hline S256 & 11 & - & 12 & 65 & 93 & 5 \\
\hline S333 & 9 & - & 11 & 65 & 88 & 5 \\
\hline B. pumilus IFO 12110 & 7 & 7 & 8 & 9 & - & 4 \\
\hline \multicolumn{7}{|l|}{ B. coagulans } \\
\hline IFO 3557 & 4 & 3 & 5 & 5 & - & - \\
\hline IFO 3886 & 4 & 3 & 4 & 5 & - & 6 \\
\hline IFO 3887 & 4 & 4 & 4 & 4 & - & - \\
\hline \multicolumn{7}{|l|}{ B. megaterium } \\
\hline IFO 3970 & 3 & 2 & 3 & 3 & - & - \\
\hline IAM 1030 & 5 & $\overline{3}$ & 3 & 3 & 5 & 100 \\
\hline $\mathrm{S} 211$ & 5 & - & 4 & 3 & 4 & 89 \\
\hline B. cereus IAM 1229 & 3 & 3 & 3 & 3 & - & 8 \\
\hline B. brevis IFO 12334 & 2 & 2 & 3 & 2 & - & - \\
\hline Escherichia coli K-12 & 1 & 1 & 1 & 1 & 2 & 2 \\
\hline
\end{tabular}

${ }^{a}$ Homology index is expressed as percentage of input DNA bound to a certain disk DNA relative to the homologous reaction. - - Not tested.

strictly to the standard description of $B$. licheniformis in Bergey's Manual $(11,22)$.

The DNA homology indexes between strains of $B$. licheniformis and strains of $B$. subtilis ranged from 8 to $15 \%$, whereas those between $B$. megaterium and $B$. subtilis, and also those between $B$. megaterium and $B$. lichenformis, were approximately $5 \%$. Strains of $B$. cereus, B. co- 
agulans, and B. megaterium showed lower homologies ( 3 to $5 \%$ ) to each input DNA, except for homologous combination in $B$. megaterium. A strain of $B$. pumilus (IFO 12110) seemed to have rather higher homology to the reference strains of $B$. subtilis (168, W23, and KA-63) and $B$. licheniformis (IFO 12107) than did the strains of $B$. cereus, $B$. coagulans, and $B$. megaterium. A strain of $B$. brevis (IFO 12334) showed the lowest degree of homogeneity to the above reference strains. $E$. coli K-12 showed significantly lower homology indexes (1 to $2 \%$ ) to any reference strains of Bacillus.

Thermal dissociation profile of hybrid DNA. Thermal dissociation profiles of hybrid DNA duplexes formed between homologous or heterologous DNAs are shown in Fig. 4. The DNA duplexes of lower homology were more unstable to heat than those of higher homology. The thermal elution midpoint, $T_{m}$, of the homologous DNA hybrid of $B$. subtilis strain 168 was about $60 \mathrm{C}$ in $6 \times \mathrm{SSC}$-formamide $(50 \%)$, and that of the heterologous duplex between $B$. subtilis strain W23 (input DNA) and strain 168 (disk DNA) was $4 \mathrm{C}$ lower than that of the homologous duplex of strain 168 . The $T_{m}$ of the heterologous duplex formed between the DNA of $B$. subtilis strain KA-63 (input DNA) and disk DNA of strain 168 (homology index of $21 \%$ ) was even lower, $49 \mathrm{C}$. The heterologous duplex between the input DNA of $B$. licheniformis

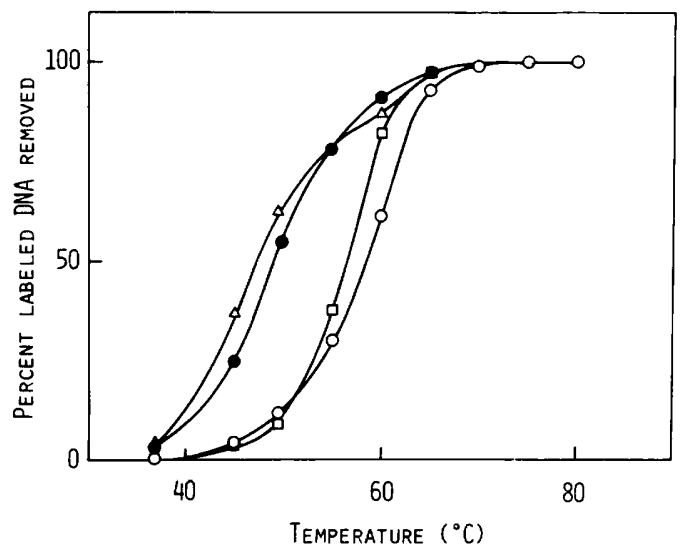

FIG. 4. Thermal dissociation profiles of DNA hybrids. The DNA hybrid duplex was formed by incubation $2.5 \mu \mathrm{g}$ of ${ }^{3} \mathrm{H}$-labeled input DNA of B. subtilis 168 (O), W23 (口), and KA-63 (O), and B. licheniformis IFO $12107(\triangle)$, with $25 \mu \mathrm{g}$ of disk DNA prepared from $B$. subtilis 168 in $1 \mathrm{ml}$ of $6 \times S S C$-formamide $(50 \%)$ at $37 \mathrm{C}$ for $22.5 \mathrm{~h}$. The hybrid duplex of DNA was dissociated by heating the filter at various temperatures for $10 \mathrm{~min}$ in $1.5 \mathrm{ml}$ of $6 \times \mathrm{SSC}$-formamide (50\%).The dissociated DNA at each temperature was collected and was determined by counting the radioactivity as described in the text. strain IFO 12107 and the disk DNA of strain 168 (homology index of $8 \%$ ) had a slightly lower $T_{m}$ value $(47 \mathrm{C})$ than the hybrid duplex of strains KA-63 and 168. Thus it appears that the homology region of a hybrid DNA duplex with lower homology may include more unpaired base sequences than that having higher homology. In these experiments, the DNA recovered by heating to $80 \mathrm{C}$ was more than $95 \%$ hybrid DNA, and DNA released from the disk DNA was about $3 \%$ by each heating at higher than $55 \mathrm{C}$ for $10 \mathrm{~min}$.

Common DNA fragment among the species. Almost the same low homology indexes (approximately 10\%) were found between DNA of $B$. licheniformis strain IFO 12107 and the DNA from either strains 168 or KA-63 of $B$. subtilis, whereas a low (21 to $23 \%$ ) homology index was observed between the DNA from strains 168 and KA-63. To compare the common DNA regions of hybrid duplexes in these combinations, the hybrid DNA duplexes were subjected to further homology tests. The DNA duplex formed on the membrane filter in either homologous or heterologous combination was dissociated by heating $(70 \mathrm{C}$ ) and rapid cooling of the filter in $1.5 \mathrm{ml}$ of $6 \times \mathrm{SSC}$-formamide $(50 \%)$. A portion $(1.0 \mathrm{ml})$ of the DNA solution obtained by this treatment was used as input DNA for the secondary hybridization with the appropriate disk DNAs. By this heating, release of input DNA prefixed on the disk DNA was more than $95 \%$. On the other hand, released disk DNA was about $3 \%$, which corresponds to $0.75 \mu \mathrm{g}$ and is a much greater amount than that of released input DNA. However, no interference was observed in the secondary hybridization of the DNA solution because the amount of disk DNA in the secondary hybridization is enough ( $25 \mu \mathrm{g}$ per disk) to avoid inhibition by the released disk DNA. The ${ }^{3} \mathrm{H}$-labeled DNA fragment originating from $B$. subtilis strain 168 and eluted from the primary duplex formed with the disk DNA of $B$. subtilis strain KA-63 (168/KA-63 fragment), and a similar DNA fragment of strain 168 from the disk DNA of $B$. licheniformis strain IFO 12107 (168/IFO 12107 fragment), were used as input DNA in the secondary hybridization with various kinds of DNA filters. The 168/IFO 12107 fragment showed 60 and $47 \%$ homologies to the disk DNA prepared from strains KA-63 and IFO 12107, respectively (Table 3 ). The 168/KA-63 fragment also showed higher homologies to these disk DNAs (55 and 26\%, respectively). Significant increments of DNA binding were always observed in a similar experiment using disk DNAs prepared from other strains, including those of $B$. megaterium, $B$. 
TABLE 3. Homology increase of the common DNA fragment

\begin{tabular}{|c|c|c|c|c|}
\hline \multirow{2}{*}{ Disk DNA } & \multirow{2}{*}{$\begin{array}{c}\text { Input DNA }{ }^{a} \\
\text { B. subtilis } \\
168\end{array}$} & \multicolumn{3}{|c|}{$\begin{array}{c}\text { Input DNA } \\
\text { (common DNA fragment of } B \text {. subtilis } 168 \text { with:) }\end{array}$} \\
\hline & & $\begin{array}{l}\text { B. subtilis } \\
168\end{array}$ & $\begin{array}{l}\text { B. subtilis } \\
\text { KA-63 }\end{array}$ & $\begin{array}{l}\text { B. licheniformis } \\
\text { IFO } 12107\end{array}$ \\
\hline $\begin{array}{l}\text { B. subtilis } \\
\quad 168 \\
\text { W23 } \\
\text { KA-63 } \\
\text { OUT } 8110 \\
\text { B. licheniformis IFO } 12107 \\
\text { B. megaterium IAM } 1030 \\
\text { B. coagulans IFO } 3886 \\
\text { Escherichia coli } \mathrm{K}-12\end{array}$ & $\begin{array}{r}100 \\
70 \\
23 \\
17 \\
8 \\
5 \\
4 \\
1\end{array}$ & $\begin{array}{r}100 \\
62 \\
26 \\
20 \\
12 \\
5 \\
5 \\
1\end{array}$ & $\begin{array}{r}100 \\
69 \\
55 \\
47 \\
26 \\
14 \\
14 \\
5\end{array}$ & $\begin{array}{r}100 \\
76 \\
60 \\
55 \\
47 \\
27 \\
26 \\
10\end{array}$ \\
\hline
\end{tabular}

${ }^{a}$ Data cited from Table 2. Numbers indicate the percentage of input DNA bound to a certain disk DNA relative to that bound to the disk DNA of strain 168 .

coagulans, and $E$. coli. On the other hand, virtually no increment was observed in secondary hybridization between the 168/168 fragment, the fragment from the homologous duplex of DNAs from strain 168, and the various disk DNAs described above. Since the radioactivity was not incorporated into RNA during the DNA labeling, the increment of the bound radioactivity in the secondary hybridization should have been due to the DNA binding and not to the binding of contaminating RNA of any form. These results (Table 3) agree well with the idea of the common region(s) of DNA, the conserved core, and suggest that the region might occur in a wide variety of Bacillus species and also in $E$. coli, whereas the homogeneities of DNA sequences among them are higher or lower depending on the species (Fig. 4).

Interstrain and interspecific transformation. The transformability of several auxotrophic genetic markers and of streptomycinand erythromycin-resistant traits of DNA preparations isolated from various Bacillus species were tested by using two Marburg strains of $B$. subtilis, 1-18 (hisB2) and LMAH (leuA8 metB5 purA16 hisA), as the recipients. The DNA preparations extracted from $B$. subtilis strain W23 and $B$. subtilis subsp. niger strain OUT 8111 , which showed $78 \%$ homology to the DNA of strain 168 (Table 2), transformed the leucine, methionine, histidine, and adenine markers to the prototrophs in strains 1-18 and LMAH. But no prototrophic transformant was recovered from the same recipient strains with the DNA samples prepared from three strains of B. subtilis, KA-63, IAM 1523, and OUT 8110 (Table 4). On the other hand, when DNA samples prepared from the $\mathrm{Str}^{\mathrm{R}}$ and/or Ery ${ }^{\mathrm{R}}$ mutants derived from strains of the KA-63 group of $B$. subtilis were used in transformation of strain 1-18 (sensitive to both antibiotics), a significant frequency of resistant transformants was recovered (Table 5), as was observed with DNA from the similar resistant mutants of strain 168. The DNAs prepared from the $\operatorname{Str}^{R}$ and/or Ery ${ }^{\mathrm{R}}$ mutants of $B$. licheniformis IFO 12107 and $12195, B$. pumilus strain IFO 12110 , $B$. megaterium strain IAM 1030 , and $B$. cereus strain IAM 1229 were also tested for the transformability of these resistance traits by using strain 1-18 as a recipient. The results showed that weak transformability of the $\operatorname{Str}^{\mathrm{R}}$ trait (2\% of that of strain 168) was observed with the DNA of B. pumilus strain IFO $12110 \mathrm{Str}^{\mathrm{H}}$ and that no significant appearance of the $\mathrm{Str}^{\mathrm{R}}$ transformant was observed with the DNA of the $\operatorname{Str}^{\mathrm{R}}$ Ery $^{\mathrm{R}}$ mutants of $B$. megaterium strain IAM 1030 or $B$. cereus strain IAM 1229. The DNA samples prepared from the two $\operatorname{Str}^{\mathrm{R}} \operatorname{Ery}^{\mathrm{R}} \mathrm{mu}$ tant strains derived from $B$. licheniformis, IFO 12107 and IFO 12195, respectively, showed low but significant transformation of strain 1-18 with respect to the $\operatorname{Str}^{\mathrm{R}}$ trait, whereas no significant Ery $^{\mathrm{R}}$ transformant appeared on the test plate containing $1 \mu \mathrm{g}$ of erythromycin per $\mathrm{ml}$. On the other hand, the DNA from one of these strains, IFO $12195 \mathrm{Str}^{\mathrm{H}} \mathrm{Ery}^{\mathrm{R}}$, produced a low but significant frequency of Ery ${ }^{\mathrm{R}}$ transformants on a test plate containing $0.2 \mu \mathrm{g}$ of erythromycin per ml (Table 5).

When DNA samples of the mutant strains of $B$. subtilis resistant to both streptomycin and erythromycin were used for transformation of strain 1-18, the $\mathrm{Str}^{\mathrm{R}}$ transformants were selected on the medium supplemented with $1 \mathrm{mg}$ of streptomycin per ml. Several colonies appearing on the plate were transferred to the same medium containing erythromycin $(1 \mu \mathrm{g} /$ $\mathrm{ml}$ ) instead of streptomycin. The results indicated that a significant number of $\operatorname{Str}^{\mathrm{R}}$ transformants were Ery $^{\mathrm{R}}$ cotransformants (experiment no. 1 in Table 6). Two double mutants of 
TABLE 4. Interstrain and interspecific transformation of B. subtilis Marburg strain LMAH ${ }^{a}$

\begin{tabular}{|c|c|c|c|c|c|}
\hline DNA & Homology $^{b}$ & leuA8 & metB5 & purA 16 & hisA \\
\hline 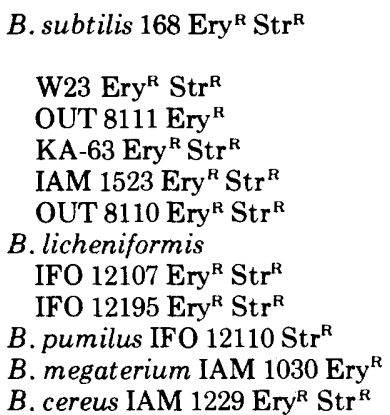 & $\begin{array}{r}100 \\
70 \\
78 \\
23 \\
20 \\
17\end{array}$ & $\begin{array}{c}\left(6.5 \times 10^{4}\right)^{c} \\
100 \\
31 \\
23 \\
<0.002 \\
<0.002 \\
<0.002 \\
\\
<0.002 \\
<0.002 \\
<0.002 \\
<0.002 \\
<0.002\end{array}$ & $\begin{array}{c}\left(5.3 \times 10^{4}\right) \\
100 \\
15 \\
8 \\
<0.002 \\
<0.002 \\
<0.002 \\
\\
<0.002 \\
<0.002 \\
<0.002 \\
<0.002 \\
<0.002\end{array}$ & $\begin{array}{l}\left(1.2 \times 10^{5}\right) \\
100 \\
14 \\
9 \\
<0.001 \\
<0.001 \\
<0.001 \\
\\
<0.001 \\
<0.001 \\
<0.001 \\
<0.001 \\
<0.001\end{array}$ & $\begin{array}{c}\left(4.4 \times 10^{4}\right) \\
100 \\
27 \\
22 \\
<0.002 \\
<0.002 \\
<0.002\end{array}$ \\
\hline
\end{tabular}

a Strain LMAH, marked with leuA8, metB5, purA 16, and hisA markers, was used as recipient.

${ }^{\circ}$ Data cited from Table 2.

${ }^{c}$ Absolute number of transformants appearing in $1 \mathrm{ml}$ of reaction mixture containing $5 \times 10^{7}$ recipient cells. All other numbers are percentages.

TABLE 5. Interstrain and interspecific transformation of B. subtilis Marburg strain 1-18

\begin{tabular}{|c|c|c|c|c|c|}
\hline DNA & Homology ${ }^{b}$ & his $B 2$ & $\begin{array}{c}\mathrm{Str}^{\mathrm{R}} \\
(1 \mathrm{mg} / \mathrm{ml})\end{array}$ & $\begin{array}{c}\operatorname{Ery}^{\mathrm{R}} \\
(1 \mu \mathrm{g} / \mathrm{ml})\end{array}$ & $\begin{array}{c}\operatorname{Ery}^{\mathrm{R}} \\
(0.2 \mu \mathrm{g} / \mathrm{ml})\end{array}$ \\
\hline B. subtilis 168 Ery $^{R} \operatorname{Str}^{R}$ & 100 & $\begin{array}{c}\left(3.9 \times 10^{4}\right)^{c} \\
100\end{array}$ & $\left(3.2 \times 10^{3}\right)$ & $\left(1.2 \times 10^{4}\right)$ & $\left(4.7 \times 10^{4}\right)$ \\
\hline W23 Ery $^{\mathrm{R}} \mathrm{Str}^{\mathrm{R}}$ & 70 & 54 & 106 & 59 & $-^{d}$ \\
\hline OUT 8111 Ery $^{\mathrm{R}}$ & 78 & 51 & - & 58 & - \\
\hline KA-63 Ery $^{R}$ Str $^{R}$ & 23 & $<0.003$ & 41 & 13 & - \\
\hline IAM 1523 Ery $^{R}$ Str $^{R}$ & 20 & $<0.003$ & 81 & 18 & - \\
\hline OUT 8110 Ery $^{R} \mathrm{Str}^{\mathrm{R}}$ & 17 & $<0.003$ & 56 & 22 & - \\
\hline \multicolumn{6}{|l|}{ B. licheniformis } \\
\hline IFO 12107 Ery $^{\mathrm{R}} \mathrm{Str}^{\mathrm{R}}$ & 8 & $<0.003$ & 10 & $<0.008$ & $<0.002$ \\
\hline IFO 12195 Ery $^{\mathrm{R}} \mathrm{Str}^{\mathrm{R}}$ & 9 & $<0.003$ & 6 & $<0.008$ & 13 \\
\hline B. pumilus IFO $12110 \mathrm{Str}^{\mathrm{R}}$ & 7 & $<0.003$ & 2 & - & - \\
\hline B. megaterium IAM 1030 Ery $^{\mathrm{R}}$ & 5 & $<0.003$ & - & $<0.008$ & $<0.002$ \\
\hline B. cereus IAM 1229 Ery $^{\mathrm{R}} \mathrm{Str}^{\mathrm{R}}$ & 3 & $<0.003$ & $<0.03$ & $<0.008$ & $<0.002$ \\
\hline
\end{tabular}

${ }^{a}$ Strain 1-18, marked with hisB2, was used as recipient.

- Data from Table 2.

c Absolute number of transformants appearing in $1 \mathrm{ml}$ of reaction mixture containing $10^{8}$ recipient cells. All other numbers are percentages.

d-, Not tested.

B. licheniformis, IFO $12107 \mathrm{Str}^{\mathrm{R}} \mathrm{Ery}^{\mathrm{R}}$ and IFO 12195 Str $^{\mathrm{K}} \mathrm{Ery}^{\mathrm{R}}$, were also tested for the cotransformability of these traits by using the same recipient, strain $1-18$. It was found that $48 \%$ of $\mathrm{Str}^{\mathrm{R}}$ transformants with the DNA from IFO $12195 \mathrm{Str}^{\mathrm{R}} \mathrm{Ery}^{\mathrm{R}}$ grew on the test medium supplemented with $0.2 \mu \mathrm{g}$ of erythromycin per $\mathrm{ml}$, whereas no Ery ${ }^{\mathrm{R}}$ transformants were recovered with the DNA from the other mutant, IFO $12107 \mathrm{Str}^{\mathrm{R}} \operatorname{Ery}^{\mathrm{R}}$ (Table 6). Furthermore, some of the Ery ${ }^{R}$ transformants were isolated on plates supplemented with $1 \mu \mathrm{g}$ of erythromycin per $\mathrm{ml}$ in the experiments with DNA from the strains of $B$. subtilis, or on plates supplemented with $0.2 \mu \mathrm{g}$ of erythromycin per ml for DNA from the $\operatorname{Str}^{\mathrm{R}}$ EryR mutant of $B$. licheniformis strain IFO 12195. It was found that a significant number of those Ery ${ }^{\mathrm{R}}$ transformants were also resistant to streptomycin $(1 \mathrm{mg} / \mathrm{ml})$ (experiment no. 2 in Table 6). No erythromycin-resistant transformant was obtained with DNA from the $\operatorname{Str}^{\mathrm{R}}$ Ery $^{\mathrm{R}}$ mutant of $B$. licheniformis strain IFO 12107 on the test plate containing either 0.2 or $1 \mu \mathrm{g}$ of erythromycin per ml. In another experiment with the same DNA from the mutant IFO $12107 \mathrm{Str}^{\mathrm{R}} \mathrm{Ery}^{\mathrm{R}}$, a significant number of Erys transformants appeared in the Ery ${ }^{\mathrm{R}}$ recipient, $B$. subtilis 1-18/KA-63 $\mathrm{Ery}^{\mathrm{R}}$, which is a derivative of strain $1-18$ by the previous transformation with DNA from the Str $^{\mathrm{R}}$ Ery ${ }^{\mathrm{R}}$ mutant of strain KA-63, on test medium containing $0.2 \mu \mathrm{g}$ of erythromycin per $\mathrm{ml}$. On the 
TABLE 6. Joint transformation of Ery $y^{\hat{\mathrm{R}}}$ and $S t r^{\mathrm{R}}$ traits

\begin{tabular}{|c|c|c|c|c|c|c|c|c|c|}
\hline \multirow[b]{2}{*}{ DNA } & \multicolumn{3}{|c|}{ Expt $1^{a}$} & \multicolumn{3}{|c|}{$\operatorname{Expt} 2^{a}$} & \multicolumn{3}{|c|}{ Expt $3^{b}$} \\
\hline & $\begin{array}{c}\text { No. of } \\
\text { Str }^{R} \\
\text { examined }^{c}\end{array}$ & $\begin{array}{l}\text { No. of } \\
\text { Stre } \\
\operatorname{Ery}^{\mathrm{R} d}\end{array}$ & $\begin{array}{c}\% \\
\text { Double }^{e}\end{array}$ & $\begin{array}{c}\text { No. of } \\
\text { Ery }^{\mathrm{R}} \\
\text { examined }^{d}\end{array}$ & $\begin{array}{l}\text { No. of } \\
\text { Ery } \\
\text { Str }^{R c}\end{array}$ & $\begin{array}{c}\% \\
\text { Double }^{e}\end{array}$ & $\begin{array}{c}\text { No. of } \\
\text { Str }^{R} \\
\text { examined }^{c}\end{array}$ & $\begin{array}{l}\text { No. of } \\
\text { Str }^{\mathrm{R}} \\
\text { Ery }^{s}\end{array}$ & $\begin{array}{c}\% \\
\text { Double }\end{array}$ \\
\hline \multicolumn{10}{|l|}{ B. subtilis } \\
\hline $168 \operatorname{Str}^{d R}$ & $-\prime$ & - & - & - & - & - & 50 & $23^{g}$ & 45 \\
\hline $168 \mathrm{Ery}^{\mathrm{R}} \mathrm{Str}^{\mathrm{R}}$ & 120 & 49 & 41 & 50 & 17 & 34 & - & - & - \\
\hline W23 Ery ${ }^{\mathrm{R}}$ Str $^{\mathrm{R}}$ & 120 & 53 & 44 & 50 & 24 & 48 & - & - & - \\
\hline KA-63 $\operatorname{Ery}^{R} \operatorname{Str}^{R}$ & 110 & 53 & 48 & 50 & 5 & 10 & - & - & - \\
\hline IAM 1523 EryR $^{R} \operatorname{Str}^{R}$ & 120 & 48 & 40 & 50 & 5 & 10 & - & - & - \\
\hline OUT 8110 Ery Str $^{\mathrm{R}}$ & 120 & 52 & 43 & 51 & 3 & 6 & - & - & - \\
\hline \multicolumn{10}{|l|}{ B. licheniformis } \\
\hline IFO 12107 Eryē $\operatorname{Str}^{R}$ & 200 & 0 & 0 & - & - & - & 92 & & 47 \\
\hline IFO 12195 Ery $^{\mathrm{R}} \mathrm{Str}^{\mathrm{R}}$ & 123 & $59^{8}$ & 48 & $100^{\mathrm{g}}$ & 3 & 3 & 53 & $28\left(0^{8}\right)$ & 53 \\
\hline B. pumilus IFO $12110 \mathrm{Str}^{\mathrm{R}}$ & - & - & - & - & - & - & 83 & $22^{8}$ & 27 \\
\hline
\end{tabular}

${ }^{a} B$. subtilis 1-18 was used as recipient.

${ }^{\circ}$ B. subtilis 1-18/KA-63 Ery ${ }^{\mathrm{R}}$, a derivative of strain 1-18 by the transformation with DNA of the strain KA-63 $\operatorname{Ery}^{\mathrm{H}} \mathrm{Str}^{\mathrm{H}}$, was used as recipient.

' Streptomycin concentration was $1 \mathrm{mg} / \mathrm{ml}$.

${ }^{d}$ Erythromycin concentration was $1 \mu \mathrm{g} / \mathrm{ml}$.

- Frequencies of joint transformation.

$t$-, Not tested.

Erythromycin concentration was $0.2 \mu \mathrm{g} / \mathrm{ml}$.

other hand, no Ery ${ }^{\mathrm{s}}$ transformants appeared in a similar experiment using the DNA from the $\operatorname{Str}^{\mathrm{R}}$ Ery $^{\mathrm{R}}$ mutant of IFO 12195 with strain 1-18/KA-63 Ery $^{\mathrm{R}}$ as the recipient on test medium containing $0.2 \mu \mathrm{g}$ of erythromycin, whereas a significant number of colonies $(53 \%)$ became sensitive on test medium containing 1 $\mu \mathrm{g}$ of the same antibiotic (experiment no. 3 in Table 6). These facts suggest that there might be two mutation sites related to the Ery ${ }^{\mathrm{R}}$ trait. According to this speculation, one of the Ery markers that occurred in the $\operatorname{Str}^{\mathrm{H}} \mathrm{Ery}{ }^{\mathrm{R}}$ mutant of $B$. licheniformis strain IFO 12107 seems to be unlinked to that of $\operatorname{Str}^{\mathrm{R}}$. Another site for Ery ${ }^{\mathrm{R}}$ mutation occurring in $B$. subtilis strain KA-63 and transformed to strain 1-18 to make the 1-18/KA-63 Ery ${ }^{\mathrm{R}}$ strain would be linked to the locus for the $\operatorname{Str}^{R}$ mutation. Alternatively, it is possible that the difference in cotransformability of the antibiotic resistance markers among these species is attributable to an unknown physiological difference in the action of erythromycin on these species. The cotransformability of these antibiotic resistance markers also appeared in the transformation of DNA from $B$. pumilus to strain $1-18 / \mathrm{KA}-63$ Ery $^{\mathrm{R}}$ (Table 6).

\section{DISCUSSION}

High DNA homologies have been reported in the interspecific and even the intergeneric DNA-DNA hybridization in Enterobacteriaceae by Falkow et al. $(2,3,5)$. According to these authors, the homology indexes between different strains of $E$. coli and between several species of Shigella, Salmonella, and Alkalescens-Dispar and $E$. coli were from 100 to $36 \%$, more than 70 , 45 , and $88 \%$, respectively, measured by the hydroxapatite binding method. De Ley et al. (6) also reported high homology indexes in Pseudomonas (100 to 55\%), except two strains which showed low homology indexes $(5 \%)$, and Xanthomonas (100 to $54 \%$ ) by interspecific DNA-DNA hybridization.

In comparison with these microorganisms, Bacillus has rather lower interspecific DNA homology indexes (Table 2). Similar lower homologies of DNA were also observed between some strains of $B$. subtilis. According to the DNA homology index data, we divided them into two groups. One of them, whose homology index to the Marburg strain was above $70 \%$, transformed auxotrophic markers widely dispersed on the chromosome and antibiotic resistance markers to the Marburg strains, LMAH and 1-18. The other group of strains in $B$. subtilis, e.g., KA-63, having DNA homology to the DNA of strain 168 of 20 to $25 \%$, did not transform auxotrophic markers to wild in strain 1-18 but did transform antibiotic resistance markers to a lesser degree compared with the homologous reaction with the Marburg strains. Similar transformation of antibiotic resistance markers to the Marburg strain was observed with the DNA samples prepared from strains of $B$. licheniformis and $B$. pumilus, these strains having 8 to $15 \%$ and $7 \%$ DNA homologies to the DNA from the Marburg strain, respectively. This fact indicated that the transformation of antibiotic resistance markers is not restricted 
within a species but is possible between different species. These arguments strongly suggest that the two groups of $B$. subtilis should not be included in the same species but should be divided into two different ones. This conclusion is supported by the fact that, according to the recent edition (8th) of Bergey's Manual (11), the separation of B. subtilis subsp. amyloliquefaciens from $B$. subtilis was adopted by the claim of Welker and Campbell $(27,28)$, while further investigation of $B$. subtilis subsp. amyloliquefaciens to show how it differs from $B$. subtilis was requested.

These two groups of $B$. subtilis strains are not easily distinguished by the conventional taxonomic procedure. To distinguish them, Welker and Campbell (28) have proposed serological examination of $\alpha$-amylase produced by these strains. However, there is some difficulty with that proposal, because we observed that some strains, even those classified in the group other than the Marburg strain, showed very low $\alpha$-amylase activity. Since we also observed (unpublished data) that the other criterion, the growth responses in $\mathrm{NaCl}(10 \%)$ medium proposed by Welker and Campbell (27), is not sufficient to classify both groups, the only effective way to distinguish these two groups at the present time might be the homology index by DNA-DNA hybridization and transformability of the auxotrophic markers.

The DNA homologies of 16 strains of $B$. licheniformis were estimated by using two strains as references. Though we observed some discrepancies with respect to the transformation of the Ery ${ }^{\mathrm{R}}$ marker between two strains tested, their DNA homologies ranged from 61 to $100 \%$. These data suggest that there are no significant differences between the 16 strains of $B$. licheniformis and that they should be grouped into one species as in the conventional taxonomic classification according to Bergey's Manual. Only one strain of B. pumilus was used in our study, but the description by Lovett and Young (16) showed that seven strains belonging to $B$. pumilus have 58 to $99 \%$ DNA homology to the reference strain, NRRL B-3275. This fact suggests that all the strains belong to one species, B. pumilus.

In conclusion, the DNA homology data so far tested with 52 strains in 8 species of Bacillus agree with the conventional taxonomic data, except for the occurrence of two groups in $B$. subtilis that should be divided into two different species. These data, however, could suggest phylogenic relationships among these species of Bacillus as summarized in a dendrogram (Fig. 5). The DNA homology index between two

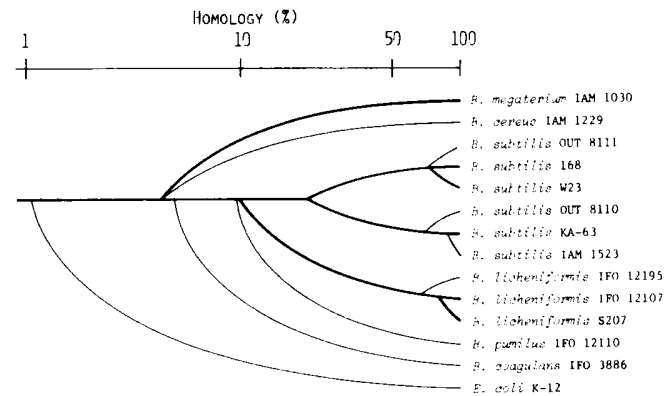

FIG. 5. Diagrammatic representation of the relation between various strains of Bacillus. Each branching point represents the percentage homology from Table 2. The reference strains are indicated by thick lines.

species is represented by the branching point on the scale. Significant increases were observed in DNA homology indexes to the DNA of the Marburg strain by the secondary hybridization experiments in all the strains so far tested, including $E$. coli $\mathrm{K}-12$. This fact strongly suggests that a specific stretch of DNA, probably coding for ribosomal RNA, transfer RNA, and ribosomal protein $(8,9)$, might be distributed among the wide variety of Bacillus species. Transformation of the Ery ${ }^{\mathrm{R}}$ and $\mathrm{Str}^{\mathrm{R}}$ markers to the Marburg strain was detected with DNA from strains showing $10 \%$ or higher DNA homology index to the DNA of the Marburg strain.

\section{ACKNOWLEDGMENTS}

We are extremely indebted to T. Yamamoto (Osaka City University), H. Yoshikawa (Kanazawa University), S. Yuki (Kobe University), and to the Institute for Fermentation and the Institute for Applied Microbiology for their generous gifts of the authentic strains used. We wish to thank N. Takada for his taxonomic advice and $H$. Tsunekawa for his expert assistance.

\section{REPRINT REQUESTS}

Address reprint requests to: Dr. Yasuji Oshima, Department of Fermentation Technology, Osaka University, Yamadakami, Suita-shi, Osaka 565, Japan.

\section{LITERATURE CITED}

1. Anagnostopoulos, C., and J. Spizizen. 1961. Requirements for transformation in Bacillus subtilis. J. Bacteriol. 81:741-746.

2. Brenner, D. J., G. R. Fanning, K. E. Johnson, R. V. Citarella, and S. Falkow. 1969. Polynucleotide sequence relationships among members of Enterobacteriaceae. J. Bacteriol. 98:637-650.

3. Brenner, D. J., G. R. Fanning, F. J. Skerman, and S. Falkow, 1972. Polynucleotide sequence divergence among strains of Escherichia coli and closely related organisms. J. Bacteriol. 109:953-965.

4. Burton, K. 1956. A study of the conditions and mechanism of the diphenylamine reaction for the colorimetric estimation of deoxyribonucleic acid. Biochem. $J$. 62:315-323.

5. Crosa, J. H., D. J. Brenner, W. H. Ewing, and S. Falkow. 
1973. Molecular relationships among the salmonelleae. J. Bacteriol. 115:307-315.

6. De Ley, J., I. W. Park, R. Tijtgat, and J. Van Ermengem. 1966. DNA homology and taxonomy of Pseudomonas and Xanthomonas. J. Gen. Microbiol. 42:43-56.

7. Denhardt, D. T. 1966. A membrane-filter technique for the detection of complementary DNA. Biochem. Biophys. Res. Commun. 23:641-646.

8. Doi, R. H., and R. T. Igarashi. 1965. Conservation of ribosomal and messenger ribonucleic acid cistrons in Bacillus species. J. Bacteriol. 90:384-390.

9. Dubnau, D., I. Smith, P. Morell, and J. Marmur. 1965. Gene conservation in Bacillus species. I. Conserved genetic and nucleic acid base sequence homologies. Proc. Natl. Acad. Sci. U.S.A. 54:491-498.

10. Dubnau, D., I. Smith, and J. Marmur. 1965. Gene conservation in Bacillus species. II. The location of genes concerned with the synthesis of ribosomal components and soluble RNA. Proc. Natl. Acad. Sci. U.S.A. 54:724-730.

11. Gibson, T., and R. E. Gordon. 1974. Endospore-forming rods and cocci. Family I. Bacillaceae, genus I. Bacilius Cohn, p. 529-550. In R. E. Buchanan and N. E. Gibbons (ed.), Bergey's manual of determinative bacteriology, 8th ed. The Williams \& Wilkins Co., Baltimore.

12. Gillespie, D., and S. Spiegelman. 1965. A quantitative assay for DNA-RNA hybrids with DNA immobilized on a membrane. J. Mol. Biol. 12:829-842.

13. Harford, N., and M. Mergeay. 1973. Interspecific transformation of rifampicin resistance in the genus Bacillus. Mol. Gen. Genet. 120:151-155.

14. Ikeda, Y., H. Saito, K. Miura, J. Takagi, and H. Aoki. 1965. DNA base composition, susceptibility to bacteriophages, and interspecific transformation as criteria for classification in the genus Bacillus. J. Gen. Appl. Microbiol. 11:181-190.

15. Kinoshita, S., H. Okada, and G. Terui. 1967. On the nature of $\alpha$-amylase forming system in Bacillus subtilis. J. Ferment. Technol. 45:504-510.

16. Lovett, P. S., and F. F. Young. 1969. Identification of
Bacillus subtilis NRRL B-3275 as a strain of Bacillus pumilus. J. Bacteriol. 100:658-661.

17. Lowry, O. H., N. J. Rosebrough, A. L. Farr, and R. J. Randall. 1951. Protein measurement with the Folin phenol reagent. J. Biol. Chem. 193:265-275.

18. Marmur, J. 1961. A procedure for the isolation of deoxyribonucleic acid from micro-organisms. J. Mol. Biol. 3:208-218.

19. Marmur, J., E. Seaman, and J. Levine. 1963. Interspecific transformation in Bacillus. J. Bacteriol. 85:461-467.

20. McConaughy, B. L., C. D. Laird, and B. J. McCarthy. 1969. Nucleic acid reassociation in formamide. Biochemistry 8:3289-3295.

21. Mejbaum, W. 1939. Über die Bestimmung kleiner Pentosemengen, insbesondere in Derivaten der Adenylsäure. Z. Physiol. Chem. 258:117-120.

22. Smith, N. R., and R. E. Gordon. 1957. Eubacteriales. family XIII. Bacillaceae, genus I. Bacillus Cohn, p. 613-634. In R. S. Breed, E. G. D. Murray, and N. R Smith (ed.), Bergey's manual of determinative bacteriology, 7th ed. The Williams \& Wilkins Co., Baltimore.

23. Smith, N. R., R. E. Gordon, and F. E. Clark. 1952 Aerobic sporeforming bacteria. U.S. Dept. of Agric. Monograph no. 16, Washington D. C.

24. Spizizen, J. 1958. Transformation of biochemically deficient strains of Bacillus subtilis by deoxyribonucleate. Proc. Natl. Acad. Sci. U.S.A. 44:1072-1078.

25. Stacey, D. A., and E. Simson. 1965. Improved method for the isolation of thymine-requiring mutants of Esche. richia coli. J. Bacteriol. 90:554-555.

26. Takahashi, H., H. Saito, and Y. Ikeda. 1966. Genetic relatedness of spore bearing bacilli studied by the DNA agar method. J. Gen. Appl. Microbiol. 12:113-118.

27. Welker, N. E., and L. L. Campbell. 1967. Unrelatedness of Bacillus amyloliquefaciens and Bacillus subtilis. J. Bacteriol. 94:1124-1130.

28. Welker, N. E., and L. L. Campbell. 1967. Comparison of the $\alpha$-amylase of Bacillus subtilis and Bacillus amyloliquefaciens. J. Bacteriol. 94:1131-1135. 